Elsevier

MBP 01134

\title{
Characterization of tubulin genes in Trypanosoma rangeli
}

\author{
Denise Esquenazi, Carlos M. Morel and Yara M. Traub-Cseko \\ Departamento de Bioquímica e Biologia Molecular, Fundação Oswaldo Cruz, Rio de Janeiro, Brazil
}

(Received 27 September 1988; accepted 13 December 1988)

\begin{abstract}
Tubulin genes in Trypanosoma rangeli, the only trypanosome besides $T$. cruzi to infect humans in America, are organized in homogeneous, alternate $\alpha$ and $\beta$ gene tandem repeats of $3.8 \mathrm{~kb}$. The basic repeat was cloned, mapped and partially sequenced. In contrast to most other eukaryotes, where tubulin genes are scattered throughout the genome, trypanosomatids so far studied are characterized by tandem arrangements of these genes with the genus Trypanosoma displaying an alternating $\alpha$ - and $\beta$-tubulin tandem repeat.
\end{abstract}

Key words: Trypanosoma rangeli; Tubulin; Gene organization; Tandem repeat; DNA sequence; Sequence homology

\section{Introduction}

Alpha and beta tubulins are the main constituents of microtubules. These proteins are very conserved through evolution, although heterogeneous subtypes have been detected [1]. In trypanosomes, the existence of different classes of microtubules brings up the possibility of a diversity of tubulin proteins, that could be accounted for by either a transcriptional or a post-translational event. Also, the existence of different developmental forms in trypanosomatids, some with and some without flagella, makes the participation of the expression of tubulin genes in the cycle necessarily important, and a good model system for the study of gene regulation in these organisms.

Tubulin genes are found in multiple copies in all organisms so far studied [1]. Trypanosomatids were the first eukaryotes in which these genes were found in tandem repeats, either of separate

Correspondence address: Yara M. Traub-Cseko, Departamento de Bioquímica e Biologia Molecular, Fundação Oswaldo Cruz, Av. Brasil 4365, Rio de Janeiro, RJ, 21045, Brazil

Abbreviations: kb, kilobase pairs; SDS, sodium dodecyl sulphate. or of alternating $\alpha$ - and $\beta$-tubulin gene blocks. In two different species of Leishmania, the majority of tubulin genes were found in separate $\alpha$ and $\beta$ repeats $[2,3]$. In two subspecies of $T$. brucei, alternating $\alpha$ - and $\beta$-tubulin genes were found mainly in repeats of 3.7 and $3.6 \mathrm{~kb}$ [4-6]. A similar arrangement was found in $T$. equiperdum (personal communication of U. Hibner to T. Seebeck, see ref. 5). In $T$. cruzi, a more complex structure was found, although at least part of the genes is in a $\alpha$ and $\beta$ tandem repeat of approximately $4 \mathrm{~kb}$ (ref. 7 , and our unpublished observations).

$T$. rangeli $[8]$ is the only trypanosome to infect humans in the Americas besides $T$. cruzi, the causative agent of Chagas' disease. Although this organism apparently does not cause a specific pathology in man, it is important from an epidemiological point of view. Its geographical distribution overlaps that of $T$. cruzi $[9,10]$, both flagellates are transmitted by triatomine bugs $[10,11]$ and infect the same mammal hosts [10-12]. Morphologically they are similar, and serological cross-reactions have been described, although there are some conflicting results [13-15]. Not much has been done to characterize $T$. rangeli at the genomic level. Frasch has demonstrated a high level of K-DNA similarity comparing schizo- 
demes of $T$. rangeli and $T$. cruzi [16].

In the present study we demonstrate that $T$. rangeli has tubulin genes organized in a similar way to the African trypanosomes.

\section{Materials and Methods}

Growth of $T$. rangeli. $T$. rangeli Venezuela was isolated by Dr. M.P. Deane from a mixed infection with $T$. cruzi from Venezuela. $T$. rangeli José is an isolate from a human mixed infection with $T$. cruzi from the Amazon region (I.K.F. Miranda et al., in preparation). Cells were grown in PHI-Lit [17] supplemented with $20 \%$ fetal calf serum at $28^{\circ} \mathrm{C}$ with weekly passages and initial concentrations of $10^{6}$ cells $\mathrm{ml}^{-1}$.

DNA preparation and digestion. $T$. rangeli and plasmid DNAs were prepared as described [18] and digested with restriction enzymes according to instructions of manufacturer (New England BioLabs, Beverly, MA, and FIOCruz, Rio de Janeiro).

Southern transfer and hybridization. Unidirectional or bidirectional Southern transfers were done as described $[20,21]$. Overnight hybridization to nick-translated probes [19] was done in $6 \times \operatorname{SSC}(1 \times \mathrm{SSC}$ is $150 \mathrm{mM} \mathrm{NaCl}, 15 \mathrm{mM} \mathrm{Na}$ citrate), $0.2 \%$ bovine serum albumin, $0.2 \%$ polyvinylpyrrolidone, $0.2 \%$ ficoll, $50 \mathrm{mM}$ Tris- $\mathrm{HCl}$, $\mathrm{pH} 7.5,0.1 \%$ Na pyrophosphate, $1 \%$ sodium dodecyl sulphate (SDS), $100 \mu \mathrm{g} / \mathrm{ml}$ sonicated and denatured herring sperm DNA and approximately $10^{6} \mathrm{cpm}$ of probe $\mathrm{ml}^{-1}$, at $65^{\circ} \mathrm{C}$. Filters were washed 4 times at $65^{\circ} \mathrm{C}$ with $1 \times \mathrm{SSC}$ and $1 \%$ SDS.

Probes. The chimeric plasmid pLT1 contains a 2$\mathrm{kb}$ Pst I insert of $L$. enrietti genomic DNA containing the entire $\alpha$-tubulin gene plus some flanking sequences, cloned into pBR322 [2]. Clone pLE $\beta 3$ has a 4-kb fragment of $L$. enrietti genomic DNA that contains one complete $\beta$-tubulin gene and spacer sequences cloned in pBR322 [22]. Both were gifts from Dr. Dyann Wirth.
Construction and partial sequencing of clones containing a repeat of tubulin genes of $T$. rangeli. T. rangeli Venezuela DNA $(50 \mu \mathrm{g})$ was digested with $B a m \mathrm{HI}$ and run in a $0.7 \%$ agarose gel. A slice of gel containing the 3.8 -kb DNA region was excised, the DNA electroeluted by a modification of the method of McDonnel et al. (23) and cloned into pBR322, using HB101 for transformation. Colonies were transferred to nitrocellulose and the filters treated as described [24]. Filters were probed with pLT1. Nucleotide sequencing was done according to standard protocols of the Sanger [25] technique.

\section{Results}

Restriction analysis of genomic DNA. Total DNA of $T$. rangeli Venezuela and José was digested with BamHI, HindIII, PstI and SalI and run in a $0.8 \%$ agarose gel. The gel was transferred bidirectionally and the filters hybridized to either pLT1 or pLEß3. Fig. 1 shows that the same bands lit up upon hybridization with both probes. The two strains evidenced the same bands with all but one enzyme. HindIII did not release the $3.8-\mathrm{kb}$ band repeat in Venezuela. BamHI, HindIII and
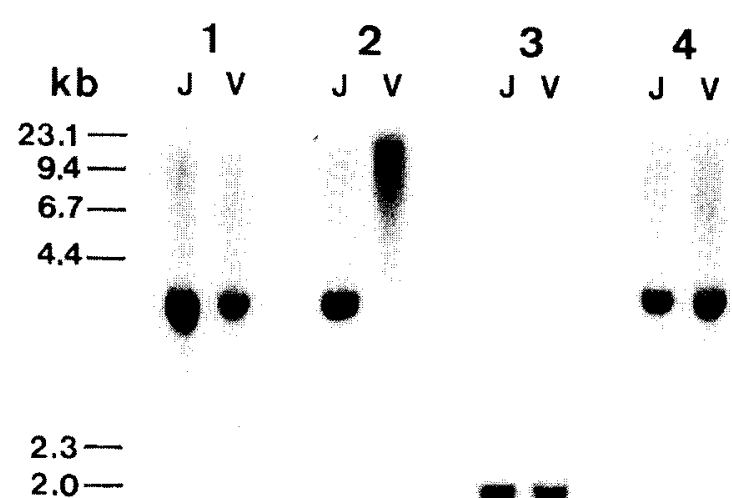

Fig. 1. Southern blot analysis of genomic DNA $(5 \mu \mathrm{g} / \mathrm{lane})$ of $T$. rangeli Venezuela (V) and José (J). DNA was digested with (1), BamHI; (2), HindIII; (3), PstI; (4), Sall, and run in a $0.8 \%$ agarose gel. After transfer, the filter was hybridized to nick-translated pLT1. The same result was obtained when hybridization was to $\mathrm{pLE} \beta 3$. 


\section{$\begin{array}{lllllll}1 & 2 & 3 & 4 & 5 & 6 & 7\end{array}$}

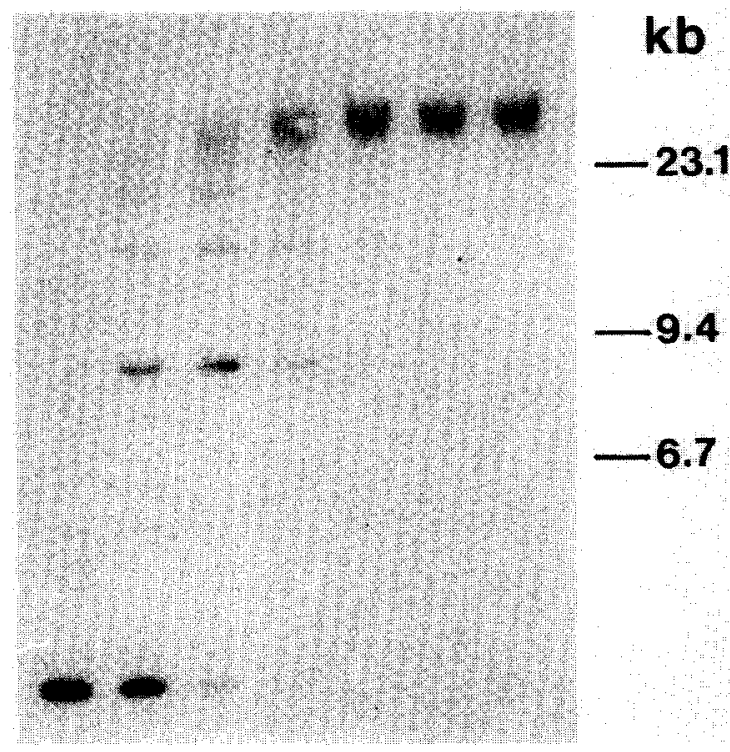

Fig. 2. Partial digestion of $T$. rangeli Venezuela DNA. DNA $(5 \mu \mathrm{g})$ was digested with 1 unit Bam $\mathrm{HI}$ for different lengths of time (1), $2 \mathrm{~h}$; (2), $1 \mathrm{~h}$; (3), $30 \mathrm{~min}$; (4), $20 \mathrm{~min}$; (5), $15 \mathrm{~min}$; (6), $10 \mathrm{~min}$; (7) $5 \mathrm{~min}$. Gel was transferred and filter hybridized to pLT1.

Sal I gave rise to a band of $3.8 \mathrm{~kb}$, and PstI to a rather broad band of approximately $1.9 \mathrm{~kb}$ that could contain half the repeat. These results were an indication of the existence of tandem repeats of alternating $\alpha$ and $\beta$-tubulin genes in $T$. rangeli.

Southern blots of partially digested DNA. The accuracy of the proposed structure was verified by partial digestion of the DNA and hybridization to the $\alpha$-tubulin probe. $T$. rangeli Venezuela DNA was digested for different lengths of time with $B a m \mathrm{HI}$, run in a $0.7 \%$ agarose gel and transferred to nitrocellulose. Upon hybridization (Fig. 2) up to 5 multiples of the repeat unit are visible. The higher molecular weight fragments are not resolved and form a cluster of strong hybridization on the top of the gel.

Quantification of tubulin genes. DNA of $T$. rangeli Venezuela $(3 \mu \mathrm{g})$ was digested with SalI and run in a $0.8 \%$ agarose gel. Increasing amounts $(0.1,0.25,0.5$ and $1 \mathrm{ng})$ of linearized $\mathrm{pLT} 1$ were run in the same gel. The Southern blot of the gel

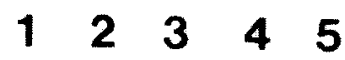

kb

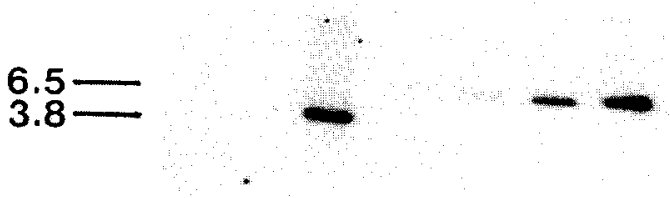

Fig. 3. Quantification of tubulin genes. DNA of $T$. rangeli Venezuela $(3 \mu \mathrm{g})$ was digested with $\mathrm{SalI}(1)$ and run in a $0.7 \%$ agarose gel together with different amounts of linearized pLT1: (2), $0.1 \mathrm{ng}$; (3), $0.25 \mathrm{ng}$; (4), $0.5 \mathrm{ng}$; (5), $1 \mathrm{ng}$. The gel was transferred and the filter hybridized to labelled pLT1.

was hybridized to pLT1 (Fig. 3). Estimating a genome size of $5 \times 10^{7}$ for $T$. rangeli from results obtained with other trypanosomatids [26,27], we calculate an approximate number of 8 repeats of tubulin genes per haploid genome. This should be considered only a rough approximation, as the exact genome size for $T$, rangeli has not yet been determined.

Cloning of the unit repeat of tubulin genes. Two Bam HI clones hybridizing against pLT1 were selected for further characterization, pRM2 and pRM4. They differed in that pRM4 contained a site for HindIII and pRM2 did not (Fig. 4), and in that they were cloned in opposite directions. These clones were cut with various restriction enzymes and the gels were transferred and hybridized to pLT1 and pLE 33 inserts. From the patterns obtained we constructed a map that is shown in Fig. 5.

Partial sequencing of clone $p R M 2$. The sequencing strategy is shown in Fig. 5. The BamHI insert of pRM2 was cut with PstI and the three fragments obtained were cloned in $\mathrm{M} 13 \mathrm{mp} 18$ and M13mp19 in both directions. The sequences obtained were compared to published $T$. brucei tub- 


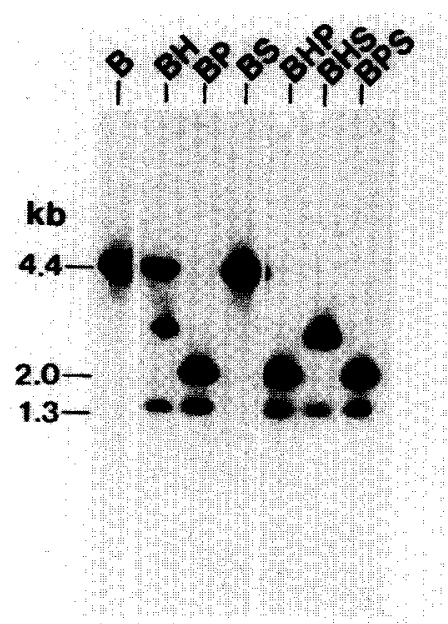

A

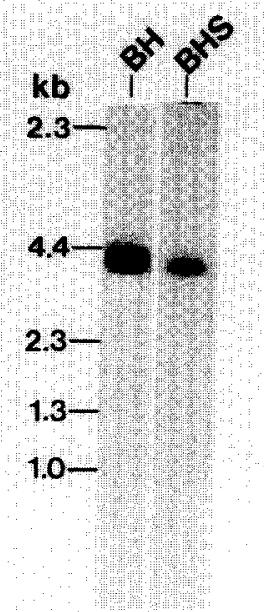

B

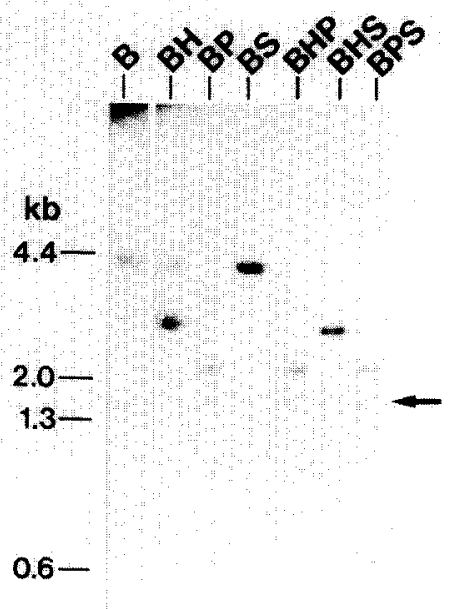

C

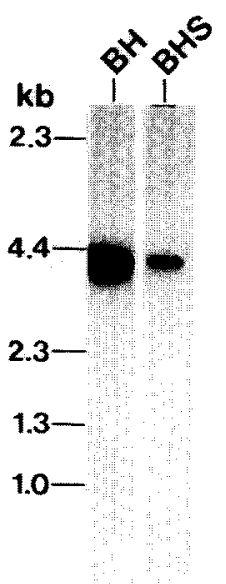

D

Fig. 4. Mapping of clones pRM2 and pRM4. $1 \mu \mathrm{g}$ of DNA from clones pRM2 (B and D) and pRM4 (A and C) was cut with BamHI (B), HindIII (H), PstI (P) and SalI (S), run in a $0.7 \%$ agarose gel and transferred bidirectionally. The filters were hybridized to labelled pLT1 insert ( $\mathrm{A}$ and $\mathrm{B})$ and pLE $\beta 3$ insert ( $\mathrm{C}$ and $\mathrm{D})$. The arrows indicate the bands that hybridize only with $\beta$ tubulin.

ulin gene sequences [6] initially by homology matrix constructions using the MicroGenie programs from Beckman, and translated using the same program. At the level of nucleotide sequences, the homology was $78 \%$, with most of the modifications at the third position of the triplet (Fig. 6). We found a homology of $98 \%$ at the level of the translated sequences. Considering the degree of homology between the $T$. rangeli and $T$. bruce $i$ sequences, it is reasonable to assume that the sizes of the genes will be the same. Under that assumption we positioned the genes on the clone (Fig. 5).

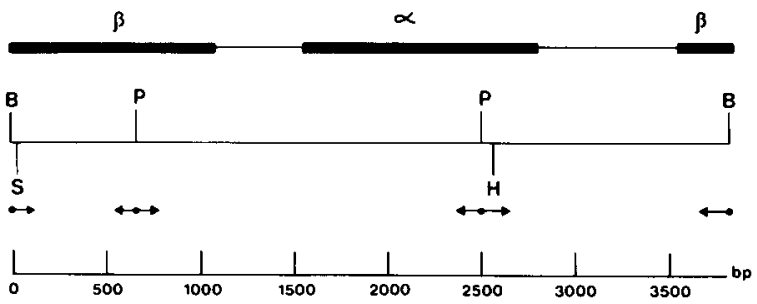

Fig. 5. Map of clones pRM2 and pRM4. B, BamHI; P, Pst I; H, HindIII; S, SalI. Arrows, sequencing strategy; bold lines, position of genes deduced from sequencing and known size of $T$. brucei tubulin genes.

\section{Discussion}

In $T$. rangeli, as in other trypanosomes so far studied, tubulin genes are arranged in an alternating repeat of $\alpha$ and $\beta$-tubulin sequences. Only one major 3.8 -kb band is seen in genomic Southern blots, even upon very long exposures, with the appearance of a faint band of $5.2 \mathrm{~kb}$ that should represent one tail end of the repeat. It would be very difficult, with this kind of monotonous structure, to have heterogeneity at the structural level of tubulin genes. If trypanosomes really have different kinds of tubulin involved in the construction of the distinct classes of microtubules, as was shown previously in Crithidia [28], this heterogeneity should most probably be given by a posttranslational event. Evidence for a post-translational modification was provided by the treatment of $T$. rhodesiense with an antibody specific for tyrosinated tubulin, which stained only the flagellar microtubules [5].

The estimated number of 8 copies of the tubulin gene repeat per haploid genome falls within what has been found for other flagellates studied [2-4].

When we compared genomic Southern blots of two different isolates of $T$. rangeli, namely Ven- 


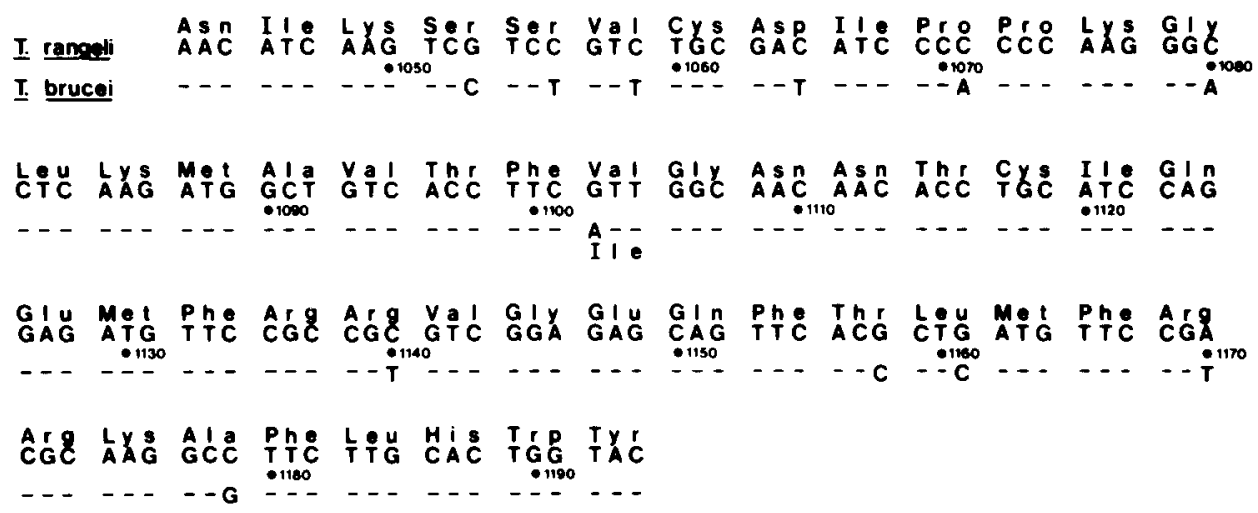

Fig. 6. Partial nucleotide sequence of the $\beta$-tubulin gene from clone pRM2. The sequence is compared and numbered according to the homologous region of the published $\beta$-tubulin gene sequence of $T$. brucei rhodesiense [14]. The $T$. rangeli sequence is shown and the deduced amino acid sequence is given above. The $T$. brucei sequence deviations are given by printing the nucleotides below the $T$. rangeli sequence, and when these changes lead to amino acid substitutions, these are also printed.

ezuela and José, we noticed that the only difference between the two was the absence of a HindIII site in the Venezuela isolate, where we could not visualize the 3.8-kb band upon hybridization with the $\alpha$ and $\beta$ probes. One of the clones obtained from $T$. rangeli Venezuela did contain the HindIII site. This class of repeat must be in the minority in the genome of this strain, since it is not visible in the genomic Southern blot. Its existence, though, is evidence that an ancestral cryptic sequence remains in the genome of this organism, and for the differential amplification of these two classes of repeats in the two strains studied.

Although $T$. rangeli is transmitted by the bite of the infected triatomine vector, it has been positioned in the subgenus Herpetosoma of the section Stercoraria [29]. More recently, this systematic position has been questioned by Añez [30] who created a subgenus, Tejerai, within the section Salivaria, to position this species. This reconsideration is given support in a WHO publication [31]. This new classification positions $T$. rangeli closer to the African trypanosomes than to $T$. cruzi. It would be necessary to study the structure of tubulin genes in more subgenera of Trypanosoma to generalize any finding, but so far it seems that the very simple organization of alternating $\alpha$ and $\beta$-tubulin genes is a characteristic of the trypanosomes from the section Salivaria. The recently published results on $T$. cruzi show a much more complex organization of these genes [7]. Our preliminary results with a few species of the section Stercoraria follow this complex pattern. In higher eukaryotes, tubulin genes are dispersed. If, as stated by Hoare [32], trypanosomes transmitted by inoculation are of more recent origin than those with a contaminative method of transmission, the more dispersed structure of these genes in the Stercoraria would make sense from an evolutionary point of view. We understand this may be an oversimplification of the available data, considering the apparent very complex genetic make-up of trypanosomes as a whole $[33,34]$.

\section{Acknowledgements}

This work was supported by grants from the UNDP/World Bank/WHO Special Programme for Research and Training in Tropical Diseases, Conselho Nacional de Desenvolvimento Científico e Tecnológico ( $\mathrm{CNPq}$ ), and Financiadora de Estudos e Projetos (FINEP). 


\section{References}

1 Cleveland, D.W. and Sullivan, K.F. (1985) Molecular biology and genetics of tubulin. Annu. Rev. Biochem. 54, 331-365

2 Landfear, S.M., McMahon-Pratt, D. and Wirth, D.F. (1983) Tandem arrangement of tubulin genes in the protozoan parasite Leishmania enrietti. Mol. Cell. Biol. 3, $1070-1076$.

3 Huang, P.L., Roberts, B.E., McMahon-Pratt, D., David, J. and Miller, J.S. (1984) Structure and arrangement of the beta tubulin genes of Leishmania tropica. Mol. Cell. Biol. 4, 1372-1383.

4 Thomashow, L.S., Millhausen, M., Rutter, W.J. and Agabian, N. (1983) Tubulin genes are tandemly linked in the genome of Trypanosoma brucei. Cell. 32, 35-43.

5 Seebek, T., Whittaker, P.A., Imboden, M.A., Hardman, N. and Braun, R. (1983) Tubulin genes of Trypanosoma brucei: a tightly clustered family of alternating genes. Proc. Natl. Acad. Sci. USA 80, 4634-4638.

6 Kimmel, B.E., Samson, S., Wu, J., Hirchberg, R. and Yarbrough, L.R. (1985) Tubulin genes of the African trypanosome Trypanosoma brucei rhodesiense: nucleotide sequence of a $3.7-\mathrm{kb}$ fragment containing genes for alpha and beta tubulins. Gene 35, 237-248.

7 Maingon, R., Gerke, R., Rodriguez, M., Urbina, J., Hoenicka, J., Negri, S., Aguirre, Y., Nehlin, J., Knapp, T. and Crampton, J. (1988) The tubulin genes of Trypanosoma cruzi. Eur. J. Biochem. 171, 285-291.

8 Tejera, E. (1920) Un nouveau flagellé de Rhodnius prolixus, Trypanosoma (ou Crithidia) rangeli n.sp. Bull. Soc. Pathol. Exot. 13, 527-530.

9 D'Alessandro, A. and DelPrado, C.E. (1977) Search for Trypanosoma rangeli in endemic areas of Trypanosoma cruzi in Argentina and Brazil. Am. J. Trop. Med. Hyg. 26, 623-627.

10 Miles, M.A., Arias, J.R., Valente, S.A.S., Naiff, R.D., de Souza, A.A., Povoa, M.M., Lima, J.A.N. and Cedillos, R.A. (1983) Vertebrate hosts and vectors of Trypanosoma rangeli in the Amazon basin of Brazil. Am. J. Trop. Med. Hyg. 32, 1251-1259.

11 D'Alessandro, A. and Mandel, S. (1969) Natural infections and behavior of Trypanosoma rangeli and Trypanosoma cruzi in the vector Rhodnius prolixus in Colombia. J. Parasitol. 55, 846-852.

12 Deane, L.M. (1958) Encontro de tripanossomo do tipo rangeli em gambás da espécie Didelphis marsupialis, no estado do Pará. Rev. Brasil. Malariol. Doenças Trop. 10, 451-458.

13 Afchain, D., LeRay, D., Fruit, J. and Capron, A. (1979) Antigenic make-up of Trypanosoma cruzi culture forms: identification of a specific component. J. Parasitol. 65, 507-514.

14 Bronzina, A.A., D'Alessandro, A. and Segura, E.L. (1980) Diferencias y similitudes antigenicas entre Trypanosoma rangeli y Trypanosoma cruzi. Medicina (Buenos Aires) 40, $45-49$.

15 Anthony, R.L., Cody, T.S. and Constantine, N.T. (1981) Antigenic differentiation of Trypanosoma cruzi and Try- panosoma rangeli by means of monoclonal-hybridoma antibody. Ann. Trop. Med. Hyg. 30, 1192-1197.

16 Frasch, A.C.C., Goijman, S.G., Cazzulo, J.J. and Stoppani, A.O.M. (1981) Constant and variable regions in DNA mini-circles from $T$. cruzi and $T$, rangeli: applications to species and stocks differentiation. Mol. Biochem. Parasitol. 4, 163-170.

17 Jaffe, C.L., Grimaldi, G. and McMahon-Pratt, D. (1984) The cultivation and cloning of Leishmania. In: Genes and Antigens of Parasites. A Laboratory Manual (Morel, C.M. ed.), 2nd ed., pp. 47-91. UNDP/World Bank/WHO Special Programme for Research and Training in Tropical Diseases, FIOCruz, Rio de Janeiro.

18 Ozaki, L.S, and Traub-Cseko, Y.M. (1984) Genomic DNA cloning and related techniques. In: Genes and Antigens of Parasites. A Laboratory Manual (Morel, C.M., ed.), 2nd ed., pp. 165-185. UNDP/World Bank/WHO Special Programme for Research and Training in Tropical Diseases, FIOCruz, Rio de Janeiro.

19 Rigby, P.W.J., Deckman, M., Rhodes, C. and Berg, P. (1977) Labelling of deoxyribonucleic acid to high specific activity in vitro by nick-translation with DNA polymerase I. J. Mol. Biol. 113, 237-251.

20 Southern, E. (1975) Detection of specific sequences among DNA fragments separated by gel electrophoresis. J. Mol. Biol. 98, 503-517.

21 Smith, G.E. and Summers, M.D. (1980) The bidirectional transfer of DNA and RNA to nitrocellulose or diazobenzyloxymethyl paper. Anal. Biochem. 109, 123-128.

22 Landfear, S.M. and Wirth, D.E. (1985) Structure of mRNA encoded by tubulin genes in Leishmania enrietti. Mol. Biochem. Parasitol. 15, 61-82.

23 McDonnel, M.W., Simon, M.N. and Studier, F.W. (1977) Analysis of restriction fragments of T7 DNA and determination of molecular weight by electrophoresis in neutral and alkaline gels. J. Mol. Biol. 110, 119-146.

24 Maniatis, T., Fritsch, E.F. and Sambrook, J. (1982) Molecular Cloning. A Laboratory Manual. Cold Spring Harbor Laboratory, Cold Spring Harbor, NY.

25 Sanger, F., Nicklen, S. and Coulson, A.R. (1977) DNA sequencing with chain terminating inhibitors. Proc. Natl. Acad. Sci. USA 74, 5463-5467.

26 Castro, C., Craig, S.P. and Castañeda, M. (1981) Genome organization and ploidy number in Trypanosoma cruzi. Mol. Biochem. Parasitol. 4, 273-282.

27 Leon, W., Fouts, D.L. and Manning, J. (1978) Sequence arrangement of 16 and $26 \mathrm{~S}$ mRNA in the pathogenic haemoflagellate Leishmania donovani. Nucleic Acids Res. 5, 491-504.

28 Russell, D.G., Miller, D. and Gull, K. (1984) Tubulin heterogeneity in the trypanosome Crithidia fasciculata. Mol. Cell. Biol. 4, 779-790.

29 Hoare, C.A. (1964) Morphological and taxonomic studies on mammalian trypanosomes, $\mathrm{X}$. Revision of the Systematics. J. Protozool. 11, 200-207.

30 Añez, N. (1982) Studies on Trypanosoma rangeli Tejera (1920) IV. A reconsideration of its systematic position. 
Mem. Inst. Oswaldo Cruz, Rio de Janeiro 77, 405-415.

31 La trypanosomiase africaine: épidémiologie et lutte (1986) Rapport d'un comité d'experts de l'OMS. OMS-Série de Rapports Techniques, 739, p. 16.

32 Hoare, C.A. (1976) In: Trypanosomes of Mammals. A Zoological Monograph. Blackwell, Oxford and Edinburgh.

33 Tibayrenc, M., Ward, P., Moya, A. and Ayala, F.J. (1986)
Natural populations of Trypanosoma cruzi, the agent of Chagas disease, have a complex multiclonal structure. Proc. Natl. Acad. Sci. USA 83, 115-119.

34 Paindavoine, P., Pays, E., Laurent, M., Geltmeyer, Y., LeRay, D., Mehlitz, D. and Steinert, M. (1986) The use of DNA hybridization and numerical taxonomy in determining relationships between Trypanosoma brucei stocks and subspecies. Parasitology 92, 31-50. 